2016

\title{
Platform for Local Political Expression and Resolution (Barcelona 1992)
}

\section{ESSEX, Stephen}

http://hdl.handle.net/10026.1/4413

Palgrave Macmillan

All content in PEARL is protected by copyright law. Author manuscripts are made available in accordance with publisher policies. Please cite only the published version using the details provided on the item record or document. In the absence of an open licence (e.g. Creative Commons), permissions for further reuse of content should be sought from the publisher or author. 
ESSEX, S. (2016) Platform for Local Political Expression and Resolution (Barcelona 1992), in BAJC, V. (Ed.) Surveilling and Securing the Olympics: From Tokyo 1964 to London 2012 and beyond, Palgrave Macmillan, Basingstoke, pp.218-237. ISBN 978-0-230-28955-0.

\author{
Platform for Local Political Expression and Resolution (Barcelona 1992) \\ Stephen Essex ${ }^{1}$
}

The Barcelona Summer Olympics of 1992 are remembered as a model of urban regeneration, especially in terms of their ability to change the spatial structure and image of the city (Garcia-Ramon and Albet, 2000; Marshall, 1996, 2000, 2004; Monclús, 2003). To the organizers, the event itself was not considered "high risk." At the global level, there were some thinking about possible reprisal attacks on competing nations in the Olympics for their involvement in the Gulf War (1990-91) (Coaffee and Johnston, 2007:146). Domestically, there was some concern that the Olympics might be used as a platform for publicity by those seeking greater political autonomy from the centralist state based in Madrid. Notably, there had been longstanding tensions in the Basque Country, Catalonia and Galicia, where a strong sense of social and cultural identity has underpinned demands for greater political and economic independence (Conversi, 1997). The location of the Games in Barcelona, the most populous and powerful city within these potentially divergent autonomous regions, obviously had particular resonance. By analysing the spatial organization of the four main Olympic venues across the city, the coordination between the multisectoral agencies involved in surveillance, and their strategies to counter any potential threat of disruption, the argument taken in this chapter suggests that in terms of security, the success of the event had more to do with political debate and the recognition that any disruption would be counterproductive to the respective causes. The principal threats to the tranquillity of the Games stemmed more from political and regional tensions within Spain than from externally-generated instability. However, in terms of security, the success of the event was partly determined by the recognition by potential dissidents that disruption to such a globally high-profile event would be counterproductive to their causes.

\title{
Barcelona as the Host City
}

The background to staging the Olympic Games in Barcelona provides an important context within which to understand perceptions of security and implementation of surveillance technologies and practices in the local and global circumstances. Barcelona, with a population of about three million, has been the economic and cultural capital of Catalonia for many centuries. During the twentieth century, the city had experienced urban and industrial decline from both changes in the global economy and General Franco's centralised dictatorship after the Spanish Civil War (1936-39). Franco's regime, based in Madrid, stifled the local government's ability to respond to the changing economic trends and acted to repress any expression of regional identity and culture. However, the death of Franco in 1975 unleashed forces for immense change that had built up by that time, including the establishment of more local powers and considerable autonomy for the regions of Spain. In Barcelona, 
these changes led to the establishment of a relatively powerful new city government and an autonomous government for Catalonia, together with the reassertion of Catalan identity and culture and a desire to position the city as a modern, post-industrial and prosperous city of world standing to attract international investment (Marshall, 1996; Monclús, 2007).

Over the decades following Franco's death, Barcelona had modernised its port and manufacturing sectors to advance its status as an economic powerhouse and transformed its older industrial urban districts into the dynamic post-industrial capital of culture that it is today. The staging of the Olympic Games in 1992 was a catalyst for much of the physical transformation, although the redevelopment was part of a longer term strategy. The General Metropolitan Plan of 1976 set out a 50-year strategy to guide the spatial adjustments necessary to modernise and sustain the port and logistics-based activities, to revitalise the waterfront and public spaces, to restore polluted and derelict industrial sites, to invest in road systems and new layouts, and to emphasise architectural design (Monclús, 2007:222-223).

Barcelona has a proud history of using mega-events to drive forward its urban development, which has included World Expos in 1888 and 1929 and, more recently, the Forum 2004 (a cultural Expo) in 2004 (Monclús, 2007). The International Olympic Committee President at the time that the Games were awarded to Barcelona in 1986, Juan Antonio Samaranch, who had been a Catalan Francoist, seemed to have been aware of the potential of the event for 'fast-tracking' the development process in his home city (Hargreaves and Ferrando, 1997:82; Hargreaves, 2000:139). Hargreaves and Ferrando (1997:86) record, for example, that when the Mayor of Barcelona, Narcís Serra, told Samaranch of the city's desire to stage the Olympics, Samaranch is said to have replied: "I accept your challenge" 2 .

Security was one of the initial concerns. When The New York Times reported about 1987 bombings by Terra Lliure, a Catalan separatist organisation, and Euzkadi Ta Askatasuna (more commonly known by its abbreviation, ETA), the Basque separatist group, it also noted that "Maragall, the Mayor [of Barcelona], said that security was of prime concern to the city's Olympic organizers". The success of this strategy in creating a new urban identity for Barcelona, and indeed for the Spanish state, therefore, seems to have depended, at least in part, upon the Olympics being perceived as a well organised and, above all, a safe and secure event ${ }^{3}$.

The award of the Olympic Games to Barcelona represented an opportunity for both the Castilian state and Catalonia to promote their respective political causes. The Spanish state wished to use the Olympics as a means of marking the end of the Franco regime $^{4}$ and to celebrate the emergence of a new, fully modernised, politically mature and unified democratic state to the rest of the world (Hargreaves and Ferrando, 1997:67). 1992 was a critical year for the country as a whole as it attempted to stage not only the Olympics in Barcelona, but the World Expo in Seville and the Cultural Capital of Europe in Madrid in what became known as the 'Spanish Project' and the 'Year of Spain'. The benefits of staging these three international events were perceived by the Spanish government as fostering pan-Spanish cooperation and better regional working relationships, as well as serving as an equalising force throughout Spain's disparate regions and attracting inward investment ${ }^{5} .1992$ was also perceived by some as Spain's final exam for membership of the club of first world, rich, democratic and organised countries (Pi-Sunyer, 1995:37). Although Spain had joined the European Community in 1986, the year of 1992 marked the creation of the Single European Market, involving the removal of economic barriers to form a 'free market' in the European Community (Wise and Gibb, 1993). Spain was positioning itself at 
the forefront of this emerging new Europe. The perception and anticipation of the potential of the Olympics for improving the international image of Spain and encouraging inward investment is nicely captured in the words of the President of the Spanish Olympic Committee and first vice president of the Organizing Committee of the 1992 Barcelona Olympic Games (COOB'92), Carlos Ferrer Salat: "Its important and fundamental that the opening and closing ceremonies of the Games help to modernise the image that foreigners have of Spain, because currently we continue to be bullfighters and flamenco dancers. If we are able to do this, this will be the best benefit possible and compensation for the effort it takes to organise the Games." 6 In contrast, public opinion in Catalonia wished to utilise the Olympics as an expression of their already existing economic wealth, aspirations for urban regeneration, and the distinctive character and culture of their region. Their goal, too, was very different, namely to further the political cause of autonomy and greater independence. The New York Times wrote, for example, that "... Catalonia, the prosperous autonomous region that has Barcelona as its capital, never misses a chance to promote its name and its nationalism - and what better chance than the Olympics?". In that same report, Jordi Pujol, President of Catalonia, was quoted as saying that "Strictly speaking, these are Barcelona's games ... But spiritually, yes, and politically and sentimentally too, these are also very much Catalonia's games".7

Recognition by the International Olympic Committee was seen as a powerful symbol of legitimacy for the aspiration of nationhood within Catalonia (Pi-Sunyer, 1995:37). On the eve of the Olympics, the Generalitat (regional government) took a two-page advertisement, at a cost of about $\$ 5.6 \mathrm{~m}$, in several European and American newspapers to promote awareness about the status of Catalonia as a 'country' within Spain. Page one of the advertisement showed the location of Barcelona on a blank map of Europe asking the question "What country do you situate this city in?". The second page gave the answer "Catalunya, of course. This is where Barcelona is, in Catalunya, a country in Spain with its own culture language and identity." 8

In addition, there were political groups in other regions in Spain, such as the Basque Country and Galicia, which could have used the Olympics as a platform to promote their claim for greater independence but not in the same way. While Catalonia recognised that it had the opportunity for entirely legitimate promotion of identity, ETA had few options other than the threat of disruptive action. The movement from the Basque Country, ETA, was more extreme and had a record of terrorist acts within Spain (Hooper, 2006). ETA was established in 1959 as a cultural movement to protect the distinctiveness of the region, but by 1963 had become more militant and had adopted revolutionary armed struggle and violence as a means of achieving its objectives (Conversi, 1997:96). ETA's campaign involved assassinations of police, the military, politicians, businessmen, journalists and academics, as well as occasional bombing in the seaside tourist resorts visited by international visitors. Such actions claimed the lives of over 800 people by 2009. The staging of the Olympics on Spanish soil presented ETA with a potential target and platform to promote its cause to a global audience (Hargreaves and Ferrando, 1997:68), although it might also have been conscious that such actions might prove counterproductive in terms of negative public opinion.

\section{Geography of Olympic facilities in Barcelona}


The geography of the sporting facilities and other infrastructure utilised for the Olympic Games of 1992 presented a fundamental challenge for the security of the event (see Figure 1). The sporting facilities were provided at four main locations across the city. The main venue for the Olympics was the Montjuïc area, which is a piece of higher ground to the south west of the city centre used as a defensive location and fortification through history. This location contained the redeveloped main stadium, originally built for the International Exposition in 1929, together with the Sant Jordi Sports Palace and the swimming and diving pools. The area had become a well-established park in the city and presented numerous access routes into and across the site. The second main venue for the Olympic events was the Vall d'Hebron area, which was a large, isolated and unstructured neighbourhood in the west of the city. This site provided the venues for cycling, archery and volleyball.

The Olympic Village was developed on a $130 \mathrm{ha} / 1.3 \mathrm{~km}^{2}$ site previously occupied by declining industries on the coast to the north east of the city centre (at Parc de Mar). Extensive redevelopment took place in this location involving the transfer of the rail route inland, the building of a coastal ring road, the removal of old industries, the construction of the Olympic Village and a new marina (Olympic Harbour). Parc de Mar was constructed as a continuation of the Eixample district and opened up $5.2 \mathrm{~km}$ of coastline previously blocked by railway lines (Essex and Chalkley, 1998; Chalkley and Essex, 1999). The fourth Olympic site, on the Diagonal, hosted the football, polo and tennis. A ring road linked the Olympic venues together, along with new traffic interchanges and a computerised traffic management system (Hargreaves, 2000:155).

\section{Organisation of Surveillance to Deliver a Secure Event}

Security considerations had been a central part of the bid process and evaluation by the International Olympic Committee. The Olympics had been awarded to Barcelona on 17 October, 1986 and by June, 1987, a Higher Commission for Olympic Security had been set up in the city to plan and implement the surveillance procedures and technologies needed to deliver a safe and secure event. A Technical Security Cabinet, involving representatives from the Organising Committee and the Higher Commission for Olympic Security, was formed in 1988 to analyse lessons from previous Olympic Games, including observation of the Calgary and Seoul Games, and to propose a model for the Barcelona event. According to the Olympic Organizing Committee report, "the Olympic security operation began in stages and in 1989 the surveillance and counter-surveillance services at the Olympic building sites and

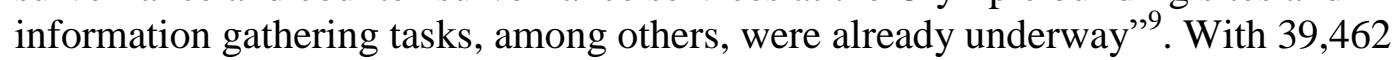
accredited members of the 'Olympic family' (including athletes, officials, media, VIPs and guests of sponsors) and nearly $0.5 \mathrm{~m}$ spectators, together with the eyes of the world on Barcelona (estimated to be $2,300 \mathrm{~m} / 2.3$ bil for the Opening Ceremony) ${ }^{10}$, the preparations to deliver security required just as much time and planning as the infrastructural developments.

The proposed model to deliver security was an integrated system of public and private plans and resources under the command of the Higher Commission for Olympic Security. Collaboration involved a huge range of surveillance operatives (see Table 1). The Olympic Security Master Plan ${ }^{11}$ was organised around three types of operational projects: (1) functions (eg. public safety, road safety); (2) specifics (eg. information security, explosive deactivation, VIP protection) and; (3) activities (eg. 
sports competition, accommodation, telecommunications, and logistics $)^{12}$. A total of 17 broad security operations were identified, within which there were 86 specific projects covering a broad range of measures to protect aspects as diverse as public safety, ticketing, telecommunications, transport and Olympic sponsorship and image rights (see Table 2). This structure evolved during the preparations for the Games. The Mayor of Barcelona was reported as saying that "We have met with teams from America's State Department and National Security Council: we're in touch with private security firms; we talked to security people from Los Angeles, and the IOC is advising us,' he said 'We're getting a lot of advice. The IOC told us we had too many agencies, 70, involved in security. We've cut that down and named a single person to be in charge of security planning." Each specific project was assigned to an organisation with a director and their own Olympic Security Office to supervise, coordinate, monitor, control and manage the risk to security ${ }^{13}$. All projects were ready by June, $1990^{14}$.

During the Games, the so-called "standard operations plans" noted above were translated into "territorial operations plans," involving a highly coordinated task force approach. Three territorial units were established with command centres (CEMAN) and coordination centres (CECOR): Level 1 (base level), where surveillance operations were carried out by the operatives at each sports venue or centre; Level 2 (area level), which brought all level 1 operations into a territorial area; and Level 3 (command level) comprising the centralised Olympic Security Centre for the whole city (Centro de Seguridad Olímpica) (see Figure 2). This hierarchical structure ensured that the lines of communication were centralised to allow operations to be properly coordinated. Centro de Seguridad Olímpica was itself linked to a Crisis Centre in Madrid should circumstances require. Such arrangements contributed to the creation of multi-scalar partnerships in Spain and so assist in reducing potential tensions and suspicions through collaboration and consensus.

The surveillance technologies and practices for the Olympic Games involved the 'Olympic Adaptation Project'. Hargreaves (2000:133) notes that most measures were implemented discreetly and were not overbearing. However, at some strategic locations, these practices and technologies were obviously conspicuous (Coafee and Johnston, 2007:147). According to the Organising Committee's report to the International Olympic Committee, "security considerations made it advisable to seal off the whole of the Olympic Village with a double line of steel fencing, and to place very strict access controls at the entrances to the residential area and the international zone." This zone included "each of the various sports facilities in the Parc de Mar Area" which also "constituted a sealed area." In addition, "the mouth of the Olympic Harbour and the beaches of the Olympic Village were protected by underwater fencing as well as by coastal patrols." So, too, "the Parc de Mar Village was a sealed area," adding to the list of strict access controls imposed at entrances to residential areas and the international zones ${ }^{15}$. About 28,725 police and armed forces personnel were deployed during the Olympics, together with an additional 8,624 volunteers and 145 contracted staff, who were hired by the Organising Committee to deal with its COOB internal company security and security at Olympic facilities during the Games period. $^{16}$

These arrangements proved successful to the organizers and the local and international audiences in that there was no serious incident. The Barcelona Director of Security, Santiago de Sicart, has subsequently acted as a security advisor for the International Olympic Committee Coordination Commissions for the Summer and Winter Olympic Games of 2000, 2002, 2004 and 2006, demonstrating the 
development of intellectual capital can become highly marketable in terms of transnational knowledge transfer for future events. The influence of these 'security experts' has therefore been longstanding, although their identity has not always been known. As the International Olympic Committee acknowledged in one of its reports, it was the "Director of Security at the Games of the XXV Olympiad in Barcelona in 1992 and [the] security expert on the 2000, 2002, 2004 and 2006 IOC Coordination Committees" who contributed research reports to the Security Working Group evaluating the bids for the 2010 Winter Olympics. ${ }^{17}$ Their names were made public by The New York Times during the time of the Salt Lake City Games: “... the security chiefs from the 1992 Barcelona Olympics and the 2000 Sydney Games, Santiago de Sicard [sic] and Peter Ryan, were acting as advisers for Salt Lake and for future Games"18.

According to Coaffee and Johnston (2007:146), a total of $\$ 66.2 \mathrm{~m}$ was spent to ensure security for the Barcelona Olympics, that is, $\$ 7,072$ per athlete.

Interestingly, this figure is considerably less than the Games immediately before or after the Barcelona Olympics (see Figure 3). The reason may be that key personnel were drawn from the Spanish military and police forces rather than private security companies. It also reflects perceptions and estimates of threats from domestic or international terrorism by the organizers of the Games.

\section{Perceptions and Estimates of Risks to Security}

There was recognition that the use of the Barcelona Olympics as a platform for publicity by regional groups seeking greater political autonomy from the state, especially in Catalonia itself and the Basque Country, had the potential, however small, to be a destabilising force for the event (Hargreaves, 2000:165), although these tensions were largely played out in symbolic terms. The 'physical' dangers anticipated were relatively modest, whereas the potential for embarrassment was the real concern. Soon after the city had won the bid to stage the event, a number of pressure groups and political parties based in Catalonia sought the 'Catalanisation' of the Games. ${ }^{19}$ One of the most prominent groups was the Associació per a la Delegació Olimpica de Catalunya which demanded, from January 1987, recognition of a Catalan Olympic Committee. The establishment of the Catalan Olympic Committee would ensure that identifying symbols of Catalonia, such as flag and national anthem, would be used if a Catalan athlete won an Olympic medal. According to a poll reported in the El País newspaper on 5 January, 1990, 86 per cent of the Catalan public supported recognition of a Catalan Olympic Committee. ${ }^{20}$ Such aspirations were shared by other groups, such as Esquerra Republicana de Catalunya (a republican political party), La Crida a la Solidaritat (Appeal for Solidarity), a militant independista pressure group campaigning for Catalan independence, and Omnium Cultural/Acció Olímpica, an influential cultural group with the backing of the party in power in regional government (Hargreaves, 2000:62). At the inauguration of the refurbished Olympic stadium on Montjuïc in September, 1989, the King of Spain and the Spanish team were jeered by the largely Catalan crowd (Hargreaves and Ferrando, 1997:68). Hargreaves (2000:65) suggests that the crowd were ill-tempered because of national propaganda circulated at the event, heavy-handed security measures, bad weather and the delayed arrival of the King.

It was concluded that a repeat of such actions during the Olympics themselves would represent a potential source of political embarrassment, which could reflect 
badly on Spain's progress in achieving national integration, identity and pride, and have negative ramifications for the country's international status. The act positioned the Olympic organisers and the Spanish government in front of a dilemma. On the one hand, they saw a need to give surveillance measures utmost priority to ensure that the Olympics in Barcelona were a successful and trouble-free event. On the other hand, allowing the regional groups to have some voice would permit the Spanish government to display its democratic credentials. After forty years of dictatorship, the State would not wish to continue to appear as a police state by suppressing and/or overriding such claims. Similarly, the regional groups were aware of the potential for alienating any support for their cause through unreasonable demands and/or unpopular acts. Neither the State nor public opinion in Catalonia had any interest in using violence as a means to achieve its goal. Consequently, there was a lot of good will and diplomacy at work, which reduced the actual risk of disruption.

The political process helped to manage the public debate over the extent of state and regional symbolism to be used in the Barcelona Games and ultimately to ensure that an appropriate compromise was reached between excessive Castilianisation and excessive Catalanisation. The Organising Committee of the Games comprised Barcelona City Council, the Catalan regional government (Generalitat), the Spanish government and the Spanish Olympic Committee, reflecting the multi-scalar collaboration required in the organisation of international events. Barcelona City Council played the key role in the preparations and was run by the Catalan Socialist Party (PSC) led by Pasqual Maragall (as Mayor). The Catalan Socialist Party is affiliated to the Spanish Socialist Workers Party (PSOE), which formed the Spanish national government in Madrid at the time. The former Mayor of Barcelona, Narcís Serra, who had instigated the Olympic bid and who had appointed Maragall, had become a key figure in Spanish national politics as Deputy Prime Minister and Minister of Defense (Hargreaves and Ferrando, 1997:67). ${ }^{21}$ Maragall's task was to stage a sufficiently Catalan event without unduly distressing opinion in Madrid (Pi-Sunyer, 1995:43), although his overriding objective was the urban regeneration of the city. In contrast, the Generalitat was run by Convergencia i Unío, a Catalan nationalist coalition, led by Jordi Pujol, a centre-right pragmatic nationalist, who was more strident in promoting regional interests with less deference to Madrid (Pi-Sunyer, 1995:43). ${ }^{22}$ His public statements often expressed strong pro-Catalan views, while others were couched in more conciliatory terms. ${ }^{23}$ Therefore, the potential political tensions were not simply between the Spanish government and the regional government, but also, to some extent, between the interests of the regional government and the city government. The views of politicians from the city and region were constantly in the forefront of mass media coverage, while contributions from Madrid were sidelined. Politicians in central government avoided any public engagement in the symbolism debate and were non-confrontational. ${ }^{24}$

Nevertheless, the 'Catalanisation' of the Olympic Games began to gain a higher profile in the pre-Olympics period. In April, 1992, Esquerra Republicana organised a three kilometre banner around the Olympic Stadium promoting their cause. It gained publicity by being the largest banner in the world for the Guinness Book of World Records. A cardboard effigy of the Barcelona Olympic mascot, Cobi, was burned. Supporters of the Catalanist movement, La Crida distributed materials including stickers, posters, clothing and a leaflet explaining the case for the 'Catalanisation' of the Games. ${ }^{25}$

On 7 May, 1992, the local political groups announced, at a press conference hosted by the Catalan Olympic Committee, La Crida, Esquerra Republicana and 
Omnium Cultural/Acció Olímpica, five minimums for the Catalan presence that would be acceptable during the Games:

- Catalan athletes must march separately under the Catalan flag

- The Catalan hymn must be used with other national anthems

- Catalan athletes who win medals must be able to choose between the Catalan and Spanish anthems at awards ceremonies

- The participating countries must march according to the alphabetical order of the Catalan language

- The International Olympic Committee must publicly state that there is no legal reason that the Catalan Olympic Committee cannot be recognised. ${ }^{26}$

The groups stated that if these minimums were not met, then there would be community demonstrations in the lead up to the opening ceremony of the Olympic Games in Barcelona. A pact (Paz Olímpica) between the Mayor of Barcelona and the President of the Generalitat (Catalan autonomous regional government) less than two months before the opening ceremony attempted to pacify the Catalan cause. The main concessions and agreements were:

- The credit for a successful Games would be shared by all participants

- The Games should be carried out peacefully in order to enhance the prestige of both Barcelona and Catalonia

- The symbols of Catalonia would be showcased at the Games

- The Spanish, Catalan and Barcelona flags will have equal status during the opening ceremony and the King of Spain would enter the stadium to the Spanish national anthem and the Catalan 'Els Segadors' hymn. Catalan would be an official language.

- Residents of Catalonia are encouraged to show their support for the Olympics by hanging banners of all types outside their homes. ${ }^{27}$

These concessions were accepted by the Esquerra Republicana political party as they sensed that public opinion had become tired of the ongoing debate. As reported in the La Vanguardia ${ }^{28}$ newspaper on 10 June, 1992, the party's president announced a 'cease-fire' over the symbolic content of Olympic ceremonies and that public pressure had stopped Spanish centralists from hijacking the Games. ${ }^{29}$ La Crida and the Catalan Olympic Committee were less content with the pact, especially regarding the use of the 'senyera' flag during the awards ceremonies for Catalan athletes. ${ }^{30}$ However, public reaction against these continued demands of the Catalan groups, as reflected in newspaper editorials and letters to the editor, began regarding them as unreasonable and disloyal. ${ }^{31}$

The threat of disruption continued in the immediate build-up to the opening ceremony on 25 July, 1992 (Hargreaves, 2000:65). The 5,570km Olympic torch run through all 17 autonomous regions of Spain in June, 1992 was disrupted by demonstrations, flags and slogans. At various points along the Olympic torch run through Catalonia to Barcelona, the flame was surrounded by demonstrators with Catalan flags chanting slogans. ${ }^{32}$ Security remained low-profile and discreet to avoid inflaming the situation and perhaps as a deliberate attempt by the authorities to show that democratic rights in the 'new' Spain were no longer restrained. It was at one such demonstration, at the coastal town of Empúries on 13 June, 1992, that press coverage, particularly in La Vanguardia and public opinion began to turn against such protests. The display of the 'Freedom for Catalonia' flag ${ }^{33}$ during a saxophone solo of 'El Cant 
dels Ocells', itself a symbol of the region, was portrayed as a shameful and inane act in newspaper coverage. The incident was not shown in the television coverage of the event. ${ }^{34}$ It soon became clear through editorials and letters to editors of newspapers, that the public was growing increasingly intolerant of any further disruption that might threaten the success of the event and that the public wanted the Games to be allowed to 'play out' peacefully (Hargreaves and Ferrando, 1997:84).

In March, shortly before the Games, a dozen ETA members were arrested because the authorities reasoned that such an arrest would diffuse the threat of attacks during the Games. As the New York Times reported, "The arrest last month of ... the leader of the Basque Homeland and Liberty organisation, known by its Spanish initials, ETA, and 11 of his associates heartened authorities that ETA might be diffused enough to pose a lesser threat to the Olympics, which begin July 25." 35 This act seems to have earned broad public support and a wave of positive feedback for the central government. ${ }^{36}$ Nevertheless, according to Toohey (2008:435), ETA did bomb electricity pylons to disrupt electricity supplies during the Opening Ceremony.

Outside of the regional political disputes, Grupo de Resistencia Antifascista Primo October ('Grapo'), a Marxist group, which inflicted attacks in various parts of Spain between 1975 and 2000, exploded bombs on a gas pipeline about 30 miles outside Barcelona during the Games. The incident was reported in the UK media:

"Juan Antonio Samaranch, the president of the IOC, denied that yesterday's bomb attack on a pipeline 30 miles outside Barcelona at Vilafranca, said to be the work of the extreme left-wing group, Grupo de Resistencia Antifascista Primo October, posed any threat to the Games, which were taking place under tight security. 'I don't think you can say that it is a threat because the incident took place nowhere near an Olympic site', he said. Police dismissed any possibility that the explosion was the work of either Basque or Catalan separatists".37

The US media also makes reference to the potential threat from Grapo:

"But one security expert in the region said the resurgence of a left-wing guerrilla group known as Grapo [Grupo de Resistencia Antifascista Primo October] also bears watching, particularly by United States interests. Grupo de Resistencia Antifascista Primo October was actively involved in the campaign several years ago to close two United States military bases in Spain, in Torrejon and Zaragoza. The Air Force finally left Torrejon two weeks ago, and the remaining American ground crews at Zaragoza will be gone by the Olympics. 'Grapo was very active a couple of years ago,' said the expert, who spoke on condition of anonymity. 'Most of the leaders ended up in jail, and six months ago, I wouldn't have thought they posed much of a problem. But then they were involved in a couple of low-grade bombings, and their leader escaped from jail last week. So I don't know what they're capable of.",38.

According to Cotterell (2003:311), both incidents caused inconvenience, but did not gain global media attention and did not disrupt the event.

During the Games, important gestures to Catalonia were made: most notably, the King declared the Games open in Catalan. Even the Spanish flag, which is perceived as a symbol of past oppression in Catalonia, appeared more frequently in the stadium and on the streets (Hargreaves and Ferrando, 1997:73-74). Some Catalan groups continued to use the Games to publicise their cause by claiming that the surveillance procedures threatened freedom of expression and civil liberties. La Crida 
described the deployment of the surveillance and security operatives as an occupation of Catalan territory (Hargreaves, 2000:80). Over 30 people were arrested for being members or supporters of a minor Catalan terrorist organisation, Terra Lliure (Free Land) (Hargreaves and Ferrando, 1997:74), which had been established as a Catalan attempt to emulate ETA (Tremlett, 2006:332). The group, in turn, understood these arrests as evidence of on-going state oppression and intimidation (Hargreaves, 2000:84). Disruption of the Olympic Games itself was nevertheless minimal, yet surveillance procedures during the Games appeared for the most part discreet and not over-bearing. Police and paramilitary drafted in from other parts of Spain were issued with guidelines on how to treat Catalans and their culture with respect. Plain-clothes police were disguised as volunteers and what was deemed 'dangerous propaganda material' was confiscated (Hargreaves, 2000:132). It may well be a testament to the measures used at the event that, in a survey of 800 Catalan residents undertaken for the La Vanguardia newspaper following the Games, the achievement of a secure event was regarded as the most successful aspect of the Barcelona Olympics by the majority of the city's population (Hargreaves and Ferrando, 1997:75-76; Hargreaves, 2000:133).

\section{Conclusion}

The organizers of the Barcelona Olympics saw domestic political groups interested in furthering their cause of regional autonomy and independence as a potential threat to security of the event, rather any disruption from external sources. Despite the extensive surveillance measures which have become a model for subsequent Olympic Games, much of the 'threat' was dissipated through dialogue, compromise, some arrests, and careful public relations and media management, together with common sense rather than confrontation or aggression. In this respect, the organisers had shown to the world that Spain was no longer ruled by a fascist regime, but was an open and democratic State. The Games played a big role in bringing maturity and pragmatism to relations between Spain, Catalonia and Barcelona and hence reduced overall political tensions. The benefits of the Olympic Games for both the greater Spanish nation-state and the regions were ultimately recognised by most interest groups and led to a struggle largely fought out in symbolic terms. The Olympic Games were allowed to be staged without being affected by terrorist acts (Hargreaves, 2000:161). Some argue that, as a result, the Barcelona Olympics acted to advance the cause of Catalan nationalism for a greater degree of autonomy within the existing democratic constitution (Hargreaves, 2000:165). Others regard the Barcelona Olympics as a missed opportunity to strengthen the region's political identity (PiSunyer, 1995:50). The International Olympic Committee, for example, refused to recognise the Catalan Olympic Committee some months after the Games in Barcelona on the grounds that Catalonia was not a state. Despite the potential threats, the Olympics themselves were safe and secure, which ultimately enabled Barcelona to establish itself as a cultural capital of Europe and a truly global city; helped the country to consolidate its rapid socio-economic maturity; and bring greater mutual acceptance to late twentieth century Spain. 
Table 1. Security forces deployed during the Barcelona Olympic Games, 1992

\begin{tabular}{|c|c|c|}
\hline Security force & Responsibility & Personnel deployed \\
\hline National Police & $\begin{array}{l}80 \% \text { of Olympic facilities } \\
\text { (venues, training sites, } \\
\text { Olympic Village and } \\
\text { official hotels) and most } \\
\text { of the functional plans }\end{array}$ & 15,500 \\
\hline Guardia Civil & $\begin{array}{l}\text { Airports, Port of } \\
\text { Barcelona, four venues, } \\
\text { essential public services } \\
\text { (water, fuel, electricity, } \\
\text { telecommunications, } \\
\text { transportation) }\end{array}$ & 5,000 \\
\hline $\begin{array}{l}\text { Mossos d'Esquadra } \\
\text { (Catalan police) }\end{array}$ & $\begin{array}{l}\text { Two competition } \\
\text { venues, crime } \\
\text { prevention activities (eg. } \\
\text { ticket touting and } \\
\text { commercial crime) }\end{array}$ & 385 \\
\hline Barcelona City Police & $\begin{array}{l}\text { Traffic and street public } \\
\text { safety. Dealing with } \\
\text { victims of crime }\end{array}$ & 2,890 \\
\hline Local Police Forces & $\begin{array}{l}\text { Within municipal } \\
\text { territories }\end{array}$ & 1,700 \\
\hline Army & $\begin{array}{l}\text { Supported Guardia Civil } \\
\text { to protect essential } \\
\text { services and human } \\
\text { resources for COOB'92 }\end{array}$ & 3,000 \\
\hline Air Force & Protection of air space & 250 \\
\hline Navy & $\begin{array}{l}\text { Territorial waters and } \\
\text { water competition areas }\end{array}$ & Undisclosed \\
\hline & Total: 28,725 \\
\hline
\end{tabular}

SOURCE: US Senate Committee on Commerce, Science and Transportation; Barcelona Olympic Organising Committee ${ }^{39}$ 
Table 2. Olympic Security Projects at the Barcelona Olympic Games, 1992

\begin{tabular}{|c|c|c|}
\hline Programme & Project & Responsible agency \\
\hline \multirow[t]{3}{*}{ Intelligence and special services } & Interior and exterior Staff, accreditations and ticket control & Department Of State Security \\
\hline & Special operations & National Police \\
\hline & Explosives detection and deactivation & Guardia Civil \\
\hline $\begin{array}{l}\text { Internal Security 1: COOB'92 } \\
\text { company security }\end{array}$ & COOB'92 company security, staff control, logistics & COOB'92 \\
\hline $\begin{array}{l}\text { Internal Security 2: accident and } \\
\text { intrusion }\end{array}$ & Physical security of Olympic facilities and surroundings & COOB'92 \\
\hline $\begin{array}{l}\text { Internal Security 3: access } \\
\text { control }\end{array}$ & Accreditations, tickets and access & COOB'92 \\
\hline \multirow[t]{2}{*}{ Transport Security } & Official transport security & National Police \\
\hline & Mobility and road security & $\begin{array}{l}\text { Barcelona City Council, local } \\
\text { police forces, Generalitat of } \\
\text { Catalonia }\end{array}$ \\
\hline Accommodation security & Accommodation and Olympic Villages security & National Police \\
\hline $\begin{array}{l}\text { Competitions, events and } \\
\text { ceremonies security }\end{array}$ & $\begin{array}{l}\text { Security for Olympic torch, ceremonies, competition and training, } \\
\text { congress, cultural event and Paralympics }\end{array}$ & National Police \\
\hline $\begin{array}{l}\text { VIP and special risk delegation } \\
\text { security }\end{array}$ & VIP security and Special risk delegation security & National Police \\
\hline \multirow{3}{*}{$\begin{array}{l}\text { Olympic support services } \\
\text { security }\end{array}$} & Olympic services security, doping control security, security air cover & National Police \\
\hline & Information security & $\begin{array}{l}\text { Ministry of Transport and } \\
\text { Communications }\end{array}$ \\
\hline & Arrival and departure management and security & Guardia Civil \\
\hline \multirow[t]{2}{*}{ Public safety } & Crime prevention, judicial police, public order, commercial crime & National Police \\
\hline & Dealing with victims of crime & City Councils \\
\hline \multirow[t]{2}{*}{ Public Services security } & $\begin{array}{l}\text { Essential public services security, Transport and communications } \\
\text { security and Frontier security }\end{array}$ & Guardia Civil \\
\hline & $\begin{array}{l}\text { Administration and control of territorial waters and air space affected by } \\
\text { the Games }\end{array}$ & Ministry of Defence \\
\hline
\end{tabular}




\begin{tabular}{|c|c|c|}
\hline \multirow[t]{8}{*}{ Emergencies } & Internal security and emergencies at Olympic sites and power & $\begin{array}{l}\text { Fire Extinction and Rescue } \\
\text { Services and Generalitat of } \\
\text { Catalonia }\end{array}$ \\
\hline & Internal security and emergencies: water supply and flood & Junta d'Aigües \\
\hline & Internal security and emergencies: telecommunications & $\begin{array}{l}\text { Department of } \\
\text { Telecommunications }\end{array}$ \\
\hline & $\begin{array}{l}\text { Internal security and emergencies: land passenger transport and of } \\
\text { dangerous materials }\end{array}$ & $\begin{array}{l}\text { Dirección General de } \\
\text { Transporte }\end{array}$ \\
\hline & Internal security and emergencies: air transport & National airports \\
\hline & Internal security and emergencies: sea transport & $\begin{array}{l}\text { Dirección General de la Marina } \\
\text { Mercante }\end{array}$ \\
\hline & Internal security and emergencies: chemicals & Genercia de Protección Civil \\
\hline & Thermal inversion emergency & Barcelona City Council \\
\hline Planning & Olympic Security Plan, monitoring basic infrastructures, tests & $\begin{array}{l}\text { Higher Commission For } \\
\text { Olympic Security }\end{array}$ \\
\hline Administration & Agreements, economics, logistics, office, legal, administration & $\begin{array}{l}\text { Higher Commission For Olympic } \\
\text { Security }\end{array}$ \\
\hline Human Resources & $\begin{array}{l}\text { Human resources management, staff selection, training, food and } \\
\text { accommodation, transport, medical and health, social and labour } \\
\text { relations }\end{array}$ & $\begin{array}{l}\text { Higher Commission For Olympic } \\
\text { Security }\end{array}$ \\
\hline \multirow[t]{2}{*}{$\begin{array}{l}\text { Telecommunications and } \\
\text { computers }\end{array}$} & Telecommunications networks and equipment & $\begin{array}{l}\text { Higher Commission For Olympic } \\
\text { Security }\end{array}$ \\
\hline & Computer networks and equipment & Department Of State Security \\
\hline Relations with the community & Image and relations with media & $\begin{array}{l}\text { Higher Commission For Olympic } \\
\text { Security }\end{array}$ \\
\hline
\end{tabular}




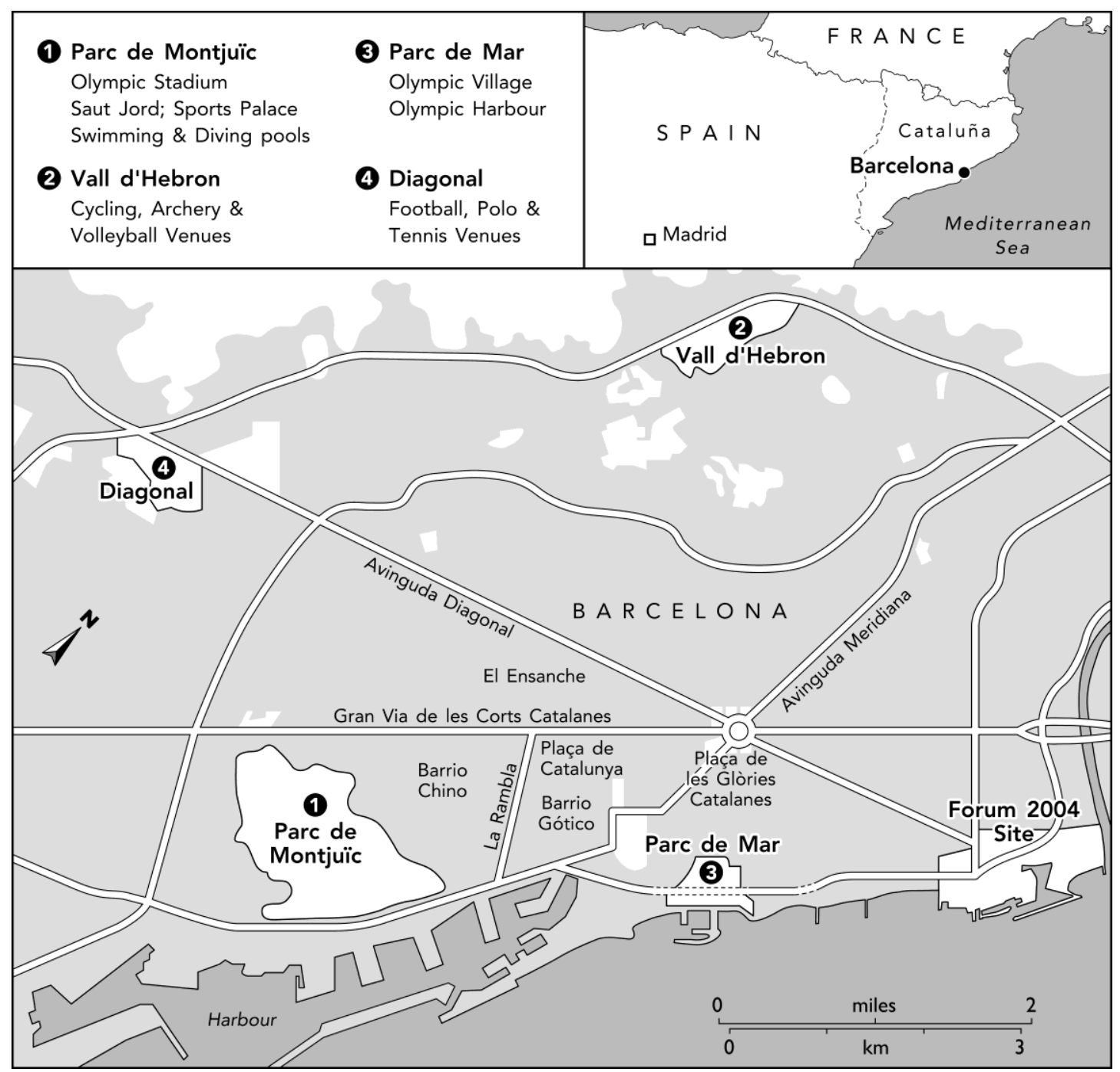

Figure 1. The location of the main venues used in the Barcelona Olympic Games in 1992 (Adapted from Essex and Chalkley, 1998, p.198) 

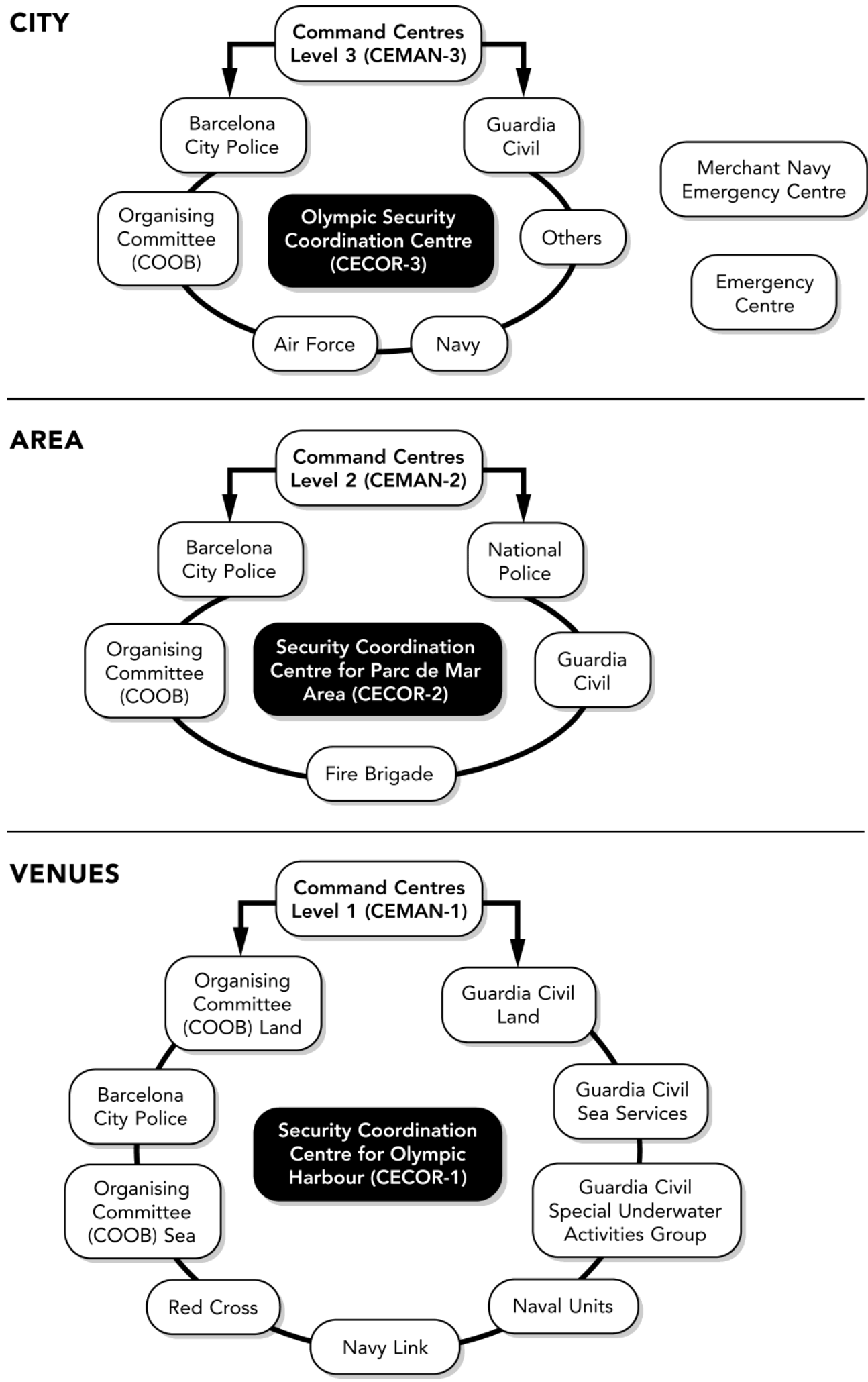

Figure 2. The organisational framework of security forces at the Barcelona Olympic Harbour (Source: Barcelona Olympic Organising Committee, 1992, p.307). 


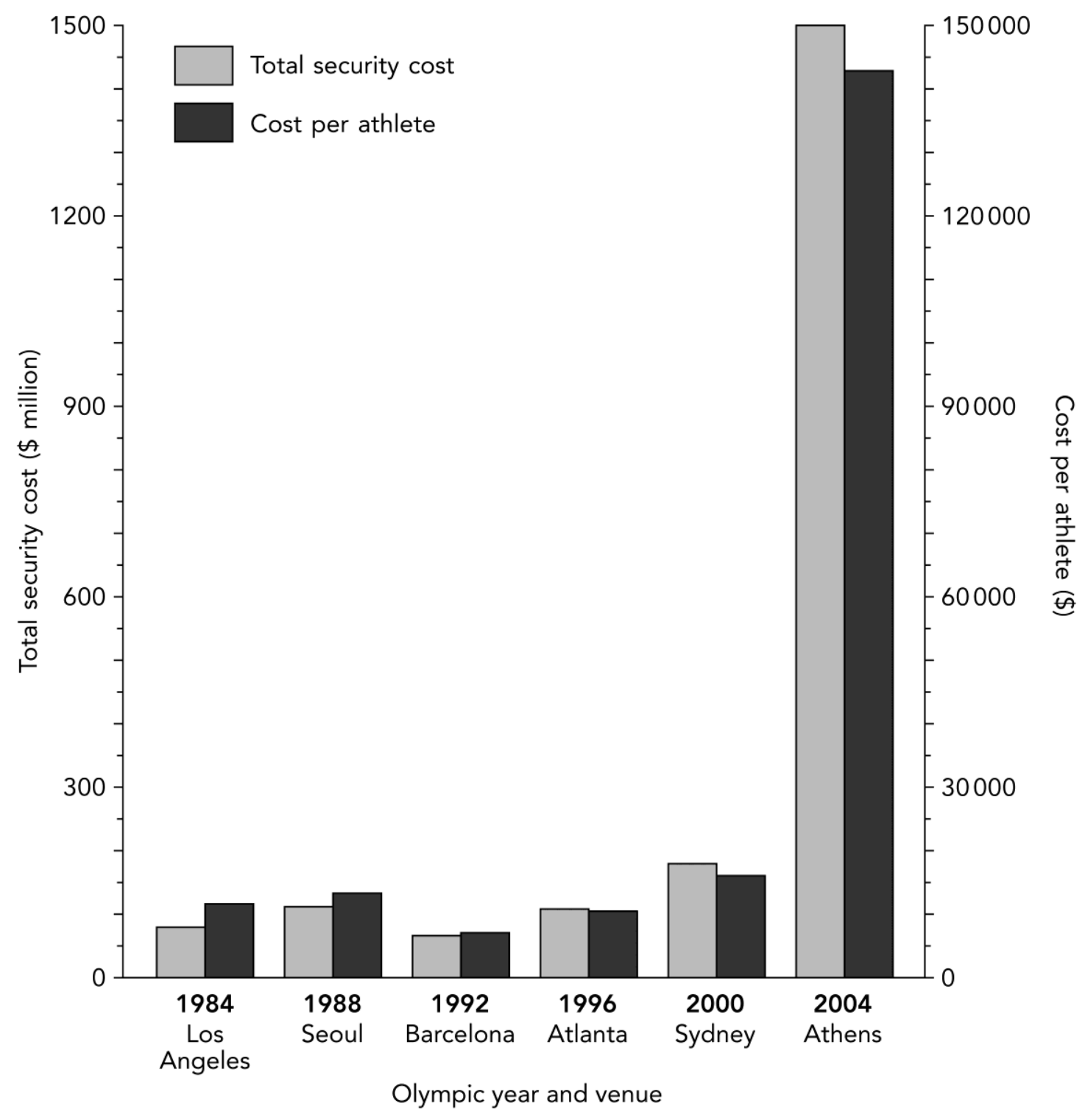

Source: Coaffee \& Johnston (2007)

Figure 3. Security costs of the Summer Olympic Games, 1984-2004

\footnotetext{
${ }^{1}$ The author wishes to thank Clive Charlton, Geoff Wilson and an anonymous referee for their valuable comments on an earlier draft of this paper. Thanks also to Brian Rogers, Tim Absalom and Jamie Quinn in the School of Geography, Earth and Environmental Sciences, Plymouth University for the cartography.

${ }^{2}$ Quoted from La Vanguardia, 14 June, 1992.

${ }^{3}$ Barcelona Plans a Lasting Olympics, by P. Delany, The New York Times, 21 October, 1987.

${ }^{4}$ Olympic Games as showcase [online article] by S. A. Harris (1992) Centre d'Estudis Olimpics UAB, Barcelona, pp 5. http://olympicstudies.uab.es/pdf/wp013_eng.pdf ${ }^{5}$ Ibid., pp. 8.

The government also undertook international publicity, involving a nine-part series of advertisement supplements in Time magazine (November, 1988-January, 1992). The
} 
nine supplements covered various topics: 'Goodbye Mañana, Hello Tomorrow', 'Renewing Spanish industry', 'Fashionable Spain', 'An Olympic Champion', 'Telecommunications and High Tech', 'A thriving Cultural Paradise', 'Spain Spearheads Europe', 'Spanish Banks Go Global' and '1992- The Year of Spain' (cited in Olympic Games as Showcase, p.12). The final supplement noted: "The end of 1992 marks Spain's full-fledged membership in the European Community and its integral role in Europe's emerging single market. These events together have created a six-year economic surge in which Spain has had the fastest growth rate in Europe. Not only did the Government embark on a massive public-spending campaign to prepare for 1992 and upgrade an outmoded infrastructure, but foreign companies flocked to Spain to take advantage of the thriving domestic economy" (cited in Olympic Games as Showcase, p.9).

${ }^{6}$ ABC Catalunya newspaper, 25 July, 1990, cited in Olympic Games as Showcase, p.11.

${ }^{7}$ Catalonia is pressing ahead as Olympic 'Country', by A. Riding, The New York Times, 18 July, 1992.

${ }^{8}$ cited in Olympic Games as Showcase, p.23.

${ }^{9}$ Barcelona Olympic Organising Committee (1992) Official Report of the Games of the XXV Olympiad, Volume 3, COOB'92, Barcelona, p.310.

${ }^{10}$ Economy of the 1992 Barcelona Olympic Games. 1993 by F. Brunet. Documents of the Museum, IOC, Lausanne, pp. 33 and 36.

${ }^{11}$ Plan Director de Seguridad Olimpica.

${ }^{12}$ Barcelona Organising Committee, 1992, p.305.

${ }^{13}$ Barcelona Plans a Lasting Olympics, by P. Delany, The New York Times, 21

October, 1987.

${ }^{14}$ Barcelona Olympic Committee (1992, p.305); US Senate Committee on

Commerce, Science and Transportation (2004) Lessons Learned from Security at Past

Olympic Games: Testimony of Mr. David Maples, 4 May, 2004. The Information

Warfare Site. http://www.iwar.org.uk/homesec/resources/olympicsecurity/maples.htm.

${ }^{15}$ Barcelona Olympic Organising Committee, 1992, pp.253-254).

${ }^{16}$ Organising Committee, 1992, pp.315

${ }^{17}$ Candidature Acceptance Procedure: XXI Olympic Winter Games in 2010, IOC, Lausanne, 2002, p. 6.

18 "Olympics: Salt Lake Olympics to review security," by Anon, The New York Times, 13 September, 2001.

${ }^{19}$ Olympic Games as Showcase, pp.19.

${ }^{20}$ Ibid. pp. 19.

${ }^{21}$ Ibid. pp.13

22 Ibid. pp. 10

${ }^{23}$ Ibid. pp. 24

${ }^{24}$ Ibid. pp. 11

${ }^{25}$ Ibid. pp. 21

${ }^{26}$ Ibid. pp. 21

${ }^{27}$ Ibid. pp. 27

${ }^{28}$ La Vanguardia is a relatively conservative newspaper based in Barcelona, but written in Spanish.

${ }^{29}$ Olympic Games as Showcase, pp. 27

${ }^{30}$ El País, 19 June, 1992, citied in Olympic Games as Showcase, pp.28. 
${ }^{31}$ Olympic Games as Showcase, pp.28

${ }^{32}$ Ibid. pp. 21

${ }^{33}$ The fact that the 'Freedom for Catalunya' flag was written in English to have maximum international impact in the media was regarded by some Catalans as counter to their cause (Olympic Games as Showcase, pp.28).

${ }^{34}$ Ibid. pp. 18

${ }^{35}$ Spain's Objective: Peaceful Games, by M. Janofsky, The New York Times, 16 April, 1992.

${ }^{36}$ Olympic Games as Showcase, pp.12

37 "Barcelona 1992: Security threat played down", by M. Rowbottom, The

Independent, 25 July, 1992

38،"Spain's Objective: Peaceful Games”, by M. Janofsky, The New York Times, 16 April, 1992.

${ }^{39}$ US Senate Committee on Commerce, Science and Transportation (2004) Lessons Learned from Security at Past Olympic Games: Testimony of Mr. David Maples, 4 May, 2004. The Information Warfare Site.

http://www.iwar.org.uk/homesec/resources/olympic-security/maples.htm; COOB'92, Barcelona Olympic Organising Committee. Official Report of the Games of the XXV Olympiad, Barcelona, Volume 3, pp. 310-312. 